\title{
Market Participation and Volume Sold: Empirical Evidence From Irrigated Crop Farmers in the Eastern Cape
}

\author{
L. Mdoda ${ }^{1} \&$ A. Obi ${ }^{1}$ \\ ${ }^{1}$ Department of Agricultural Economics and Extension, University of Fort Hare, Alice, South Africa \\ Correspondence: Lelethu Mdoda, Department of Agricultural Economics and Extension, University of Fort Hare, \\ Alice, ON, P/Bag x1314, South Africa. Tel: 27-406-022-431. E-mail: lelethu.mdoda@gmail.com
}

Received: March 19, 2019

Accepted: July 2, 2019 Online Published: October 15, 2019

doi:10.5539/jas.v11n17p66

URL: https://doi.org/10.5539/jas.v11n17p66

The research is financed by the NRF DAAD-In Country scholarship and Water Research Commission (WRC).

\begin{abstract}
The market partaking of smallholder farmers in market-oriented production has the perspective to expand profits, upsurge agricultural output and ultimately promote food security. However, the participation of smallholder's irrigators and homestead gardeners in markets in South Africa remains low despite numerous interventions, especially since the dawn of democracy in 1994. However, up-to-date, there is not enough evidence that these attempts had been met successfully. This paper examines factors influencing smallholders' choice to partake in markets and volume sold in the Eastern Cape Province. The study employed survey data of 150 irrigated crop farmers. A random sampling procedure was used in the study areas. The study used a Heckman regression to assess factors impelling market participation and volume sold. Results reveal that market participation and volume sold are influenced by socio-economic and technical factors. Based on the results, the needed policy change to encourage group marketing and upgrading of roads to enable smooth accessibility of output markets are highlighted.
\end{abstract}

Keywords: smallholder irrigators, market participation, Heckman model, Eastern Cape, crop

\section{Introduction}

Agriculture plays a dynamic role in determining the economic, political and social systems of the developing world and remains the major building block in the achievement of Sustainable Development Goals for 2030 (SDGs). Agriculture is widely seen as an imperative factor in the alleviation of poverty and income generating in Africa, especially crop production (Aliber \& Hall, 2012; DAFF, 2010). Crop production is the imperative factor because the crop is a source of vegetable protein, which is used as an easy substitute for animal protein for the mainstream of the remote and urban areas in South Africa which contains vitamins B (Samboko, 2011). Researchers argued that agriculture is estimated to be a source of living and livelihood to $86 \%$ of the people who reside in rural areas. Agriculture is (as well as further a) source of employment to almost 1.3 billion farmers and dispossessed employees in South Africa (Matsane \& Oyekale, 2014). As a result of high dependency on agriculture for livelihoods, about $48.3 \%$ of the South African population is living below the poverty line especially in the Eastern Cape Province.

For the past 18 years, the South African government has implemented many programs and policies aimed at assisting rural farmers. However, up-to-date, there is not enough evidence that these attempts had been successful in alleviating the challenges smallholder farmers faced such as deprived substructures, absence of market information, deprived market access and high transaction costs. Market participation in agricultural products is mainly promoted as a pathway for rural development, poverty alleviation, income generation and rural economic growth (IFAD, 2010). In spite of several interventions since the dawn of democracy in 1994, market participation and access is still low for smallholder farmers and smallholder's irrigation farmers in South Africa. As a result of low involvement in the market participation and poor market infrastructure; there is a dearth of market information; insufficient expertise, which results in commercialization bottlenecks due to high transaction costs and poor market access (Baloyi, 2010; Komarek, 2010; Bushoborozi, 2013; Makhura, 2001). Additionally, the confronted constraints of market participation result in farmers failing to meet the set targets in 
transforming smallholder farming to commercial farming and redressing the challenges which threaten the country's agricultural sector and SDGs goals.

Market challenges are the greatest barriers for smallholder farmers in participating in markets because these barriers affect farmer's decision making in the transformation of the agricultural sector (Baloyi, 2010). Smallholder farmers frequently lack business knowledge, negotiating experience and collective bargaining skills to interact on equal terms with strong market intermediaries consequently resulting in poor terms of exchange. Additionally, smallholder farmers find it informal to access markets, but absorbent one's location in the market is more challenging and their participation in valued markets is unsatisfactory (Matsane \& Oyekale, 2014). The aim of this paper is to analyze the issues manipulating market participation and volume sold by smallholder irrigators in the Eastern Cape Province. The paper is structured as follows; the introduction, conceptual framework, resources and methods, results and discussion as well as conclusion and recommendations.

\section{Material and Methods}

\subsection{Study Area and Research Design}

The study was done in the Eastern Cape Province of South Africa and is the third most populated Jurisdiction in South Africa with 6562053 (12.7\%) after Gauteng and KwaZulu Natal Province, which are estimated to have populations of 12272263 million (23.7\% of national) and 10267300 million (10.8\%), respectively (Hlomendlini, 2015; DEDEAT, 2013). The Province is made up of 5 Districts and 2 Metropolitan Municipalities. The average poverty level of the Province was estimated at 74.9\% (StatsSA, 2013) and the Province's level of food insecurity (78\%) is above the average national level of 64\% (DEDEAT, 2013). The Province is branded by high ranks of food insecurity and about $78 \%$ of the Provinces' households are categorized as food insecure. Majority of the dwellers in the Eastern Cape derive their livelihoods from agriculture. Hlomendlini (2015) stated that a large percentage of households in the Province who are involved in farming is in most cases not farming for business and income rather they are practicing farming to supplement other income sources and for household purposes.

The research paper used a cross-sectional design where the data was collected one point in time between growing seasons of 2015/16 and 2016/17. The data collected was on several variables such as demographics, market participation, farmer socio-economic factors, and market. The study was principally focused on smallholder farmers in order to detention their production and marketing decisions.

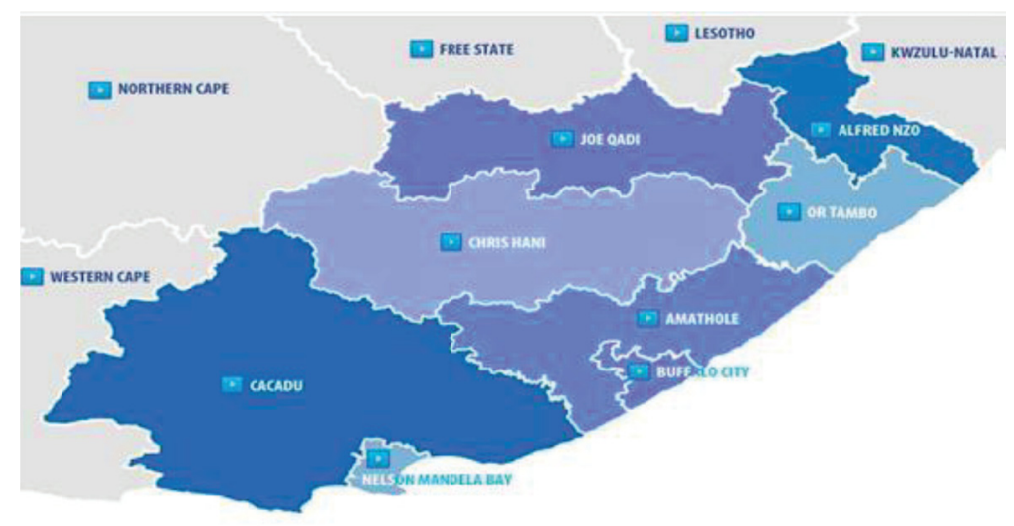

Figure 1. Study area in the Eastern Cape Province

Source: Census, 2011.

\subsection{Sampling Procedure, Sampling Frame, and Sample Size}

The study was commenced in the Eastern Cape Province of South Africa, three Regional Municipalities (O R Tambo, Amatole and Chris Hani) were considered. These regional Municipalities were chosen largely because of their agricultural potential, excessive soils which suits crop productivity as well as livestock farming. The study adopted a simple random sampling technique based on a list of fish farmers that were collected from the Department of Rural Development and Agrarian Reform in the Eastern Cape Province, which were purposively selected and within which 150 food plot-holders were enumerated. 


\subsection{Data Collection}

Data collection was collected using primary and secondary data respectively. As for secondary data, discussions were apprehended at the Regional level with representatives of the Department of Agriculture, Forestry and Fisheries (DAFF), Department of Rural Development and Agrarian Reform (DRDAR), Extension officers, Farm Organizations, farmers and Chiefs. These discussions were of great help in retrieving aforementioned studies conducted in the study area, on linked subjects and gaining understandings into present and potential strategy initiatives for the area and the sector as a whole. Overall, data and information obtained at this stage were supportive of outlining and gaining a deeper understanding of the study area.

For the determination of gathering primary data, the study applied an orderly and multipronged data collection process. Primary data were collected through a once off farmer assessment and household's survey using a organized and semi-structured questionnaire were used to generate socio-economic characteristics, invention and marketing information that changes from household to household. The questionnaire was designed in such a way that the principal portion covers the socio-economic variables such as the age of the household head, size of the household, off-farm income, and gender, etc. The subsequent fragment of the questionnaire split with the marketing and issues influencing marketing. Table 1 presents appropriate data gathered by this process. Data was collected through survey, group meetings and focus groups as to produce community-level data as well as a addition information acquired from the extension personnel and official sources in respect to broader patterns and trends that have consequences for the agricultural sector in general. Data entry, data cleaning, management of missing data and descriptive analysis were done using SPSS software and assessment of technical efficiency was done using STATA software.

\subsection{The Model}

The study makes use of the Heckman regression model to estimate challenges offensive the extent of market participation by smallholder crop irrigators in the study area. In order to survey, issues manipulating farmers' participation in markets, the Probit model was used to examine farmers decision to participates in makets or not and was the principal phase of the Heckman model. A probit model is a requirement for an ordinal or a binary response model which employs a return function. The model analysis involves binary data and at this case, market partaking is a qualitative dependent variable where it takes the values 0 and 1 , which is binary (Basamba et al., 2012). The Probit model estimates that the noticeable dependent variable, Yi, is determined as follows, given the latent (unobservable) random variable $\mathrm{y}^{*} \mathrm{i}$. A Probit model is an econometric model in which the dependent variable $\mathrm{Yi}$ can be only 1 or 0 , and the independent variables $\mathrm{x}$ is are estimated as:

$$
\operatorname{Pr}(\mathrm{Yi}=1)=\mathrm{F}\left(\mathrm{Xi}^{\prime} \beta\right)
$$

Where, $\beta$ is a factor to be estimated, and $\mathrm{F}$ is the standard Cumulative Distribution.

$$
\begin{gathered}
\mathrm{Yi}=1 \text { if } \mathrm{y}^{*} \mathrm{i}>0 \\
\mathrm{Yi}=0 \text { if } \mathrm{y}^{*} \mathrm{i}<0
\end{gathered}
$$

Given that $\mathrm{y}^{*} \mathrm{i}=\beta \mathrm{X}^{*} \mathrm{i}+\mathrm{u}{ }^{*} \mathrm{i}$, then the likelihood that you $=1$ is given as,

$$
\mathrm{Pi}=\operatorname{Prob}[\mathrm{u} * \mathrm{i}>-\beta \mathrm{Xi}]=\mathrm{F}(\beta \mathrm{Xi})
$$

Where, $\mathrm{F}(\beta \mathrm{Xi})$ is the cumulative density function $(\mathrm{CDF})$.

The probit model is then resulting by permitting $\mathrm{F}(\beta \mathrm{Xi})$ be the $\mathrm{CDF}$ of a regular normal random variable. The experimental probit used to assess the market participation function is specified as,

$$
Y i=\beta X i+e ; i=1, \ldots n
$$

Where, Yi are the reliant on variable which takes a values of 1 if the farmers participate in markets and value of 0 if the farmers do not. $\beta$ is a vector of factors to be assessed. $\mathrm{X}$ is a vector of instructive variables hypothesized to influence the likelihood of households partaking in agro-products markets. e is the random disturbance term.

\subsection{Heckman Model}

The second stage made use of the Heckman selection model to investigate issues affecting the volume of crops sold to the markets by smallholder farmers. The additional stage made use of approximations by usual least squares regression to create factors that influence the level of market participation for farmers that sold crops. The value of crops marketed is an endless dependent variable and thus OLS allows us to assessment the relationship between the dependent variable and explanatory variables. 
General model:

$$
\mathrm{r}=\beta 0+\beta 1 \mathrm{X} 1+\beta 2 \mathrm{X} 2+\beta 3 \mathrm{X} 3+\ldots+\beta \mathrm{nXn}+\mathrm{U}
$$

Where, $\mathrm{r}$ is dependent variable (maize output); $\mathrm{X} 1, \ldots \mathrm{Xn}$ are descriptive variables; $\beta$ are the estimated parameters; $\mathrm{U}$ is the disturbance term.

$$
\begin{aligned}
& \text { Value Sold }=\beta 0+\beta 1 \text { Gender }+\beta 2 \text { Educatn }+\beta 3 \text { Age }+\beta 4 \text { Hhsz }+\beta 5 \text { Farmgrp }+ \\
& \\
& \beta 6 \text { Famexp }+\beta 7 \text { Nonfarm }+\beta b 8 \text { Labr }+\beta 9 \text { Trneqp }+\beta 10 \text { Haused }+ \\
& \beta 11 \text { Transcost }+\beta 12 \text { Extsrv }+\beta 13 \text { Fmacrop }+\beta 14 \text { Distnc }+ \text { Ui }
\end{aligned}
$$

\subsection{Data}

\begin{tabular}{|c|c|c|c|}
\hline Dependent Variable & Meaning & Value & $\begin{array}{l}\text { Theorized } \\
\text { Relationship }\end{array}$ \\
\hline PIM & Participate in markets & $\begin{array}{l}\text { Dummy variable code } 1 \text { if participate in markets, } \\
0 \text { otherwise }\end{array}$ & \\
\hline Sales & Sales of crop & continuous & \\
\hline Independent Variable & Definition & Value & \\
\hline AGE & Age of the household head & Continuous & $+/-$ \\
\hline YRSPSCHL & Years spent in school by the household head & Continuous & $+/-$ \\
\hline MART & Marital status of the household head & A dummy variable coded 1 if married, 0 otherwise & $+/-$ \\
\hline HHSIZE & Household size of the farmer & Number of people in the household & $+/-$ \\
\hline IRR & Use of irrigation wate & A dummy variable coded 1 if irrigate, 0 otherwise & + \\
\hline EXT & Access to extension services by households head & & \\
\hline GEN & Gender of household men & Dummy: $1=$ if male; $0=$ otherwise & + \\
\hline MFO & Member of farm organization of farmers & Dummy: 1 if member, o if otherwise) & + \\
\hline FMS & Farm size you have access to & Hectares (Data collected in hectares & + \\
\hline HHIN & Total Annual Household Income of households head & South African Rands & + \\
\hline OFINC & $\begin{array}{l}\text { The proportion of Off-Farm Income Income of } \\
\text { households head }\end{array}$ & Ratio & $+/-$ \\
\hline DSTNC & Distance to markets & The actual distance to markets & $+/-$ \\
\hline ACRE farmer & Access to credit by a & $\begin{array}{l}\text { Dummy: } 1=\text { if farmer applied and received credit; } \\
0=\text { otherwise }\end{array}$ & $+/-$ \\
\hline
\end{tabular}

This section deals with data to collected as to makes sure it is what variables agreed to work it. The variables composed in the field survey are presented in Table 1 and explained below.

Table 1. Factors affecting market participation and volume sold

Source: Field survey (2017).

\section{Results and Discussion}

\subsection{Socio-demographic Characteristics of the Farmers}

Descriptive analysis indicated that only $40 \%$ (or what) was involved in market participation and the same margin did sell their produce to the markets. Mainstream of the farm are headed by males with a proportion of $68.5 \%$ while $31.5 \%$ were females headed by smallholder irrigated crop farmers. These results are in line with previous researchers' results who found that men are recently participating more in farming (Gobena, 2012; Kibrige, 2013). The study results reveals that average age of farmers' head among smallholder irrigators is 60 years and it means agriculture in rural areas is dominated and done by old people. Majority of farmers who are $59 \%$ had primary education as they spend approximately 5 years in school and it indicates that smallholder irrigators are literate. Family size of farmers was found to be 4 people per household by a superior proportion of $59.80 \%$ of the total farmers and they have contributed immensely to family labor supply. Mainstream of farmers are taking farming as their full-time occupation and most of the farmers have reasonable years of farming involvement that ranged from 11 years and above with $44 \%$ from the total number interviewed. The farm size in which these farmers have access to and practice their farming ranges between 0.5 to $6.0 \mathrm{Ha}$.

The study reveals that the crops grown by irrigated crop farmers were only four crops grown and the study made use of four crops grown by smallholder irrigators in the Province. According to Cousin (2013), the majority of smallholder irrigators grow crops throughout the year, while the vegetables are grown in winter and maize in 
summer as they time summer rainfall. Smallholder irrigators during their crop production follow a communal crop rotation in their farming, which comprises of ploughing maize and potatoes during summer rainfall from August to December and vegetable crops from May to August during the winter season (Christian, 2015; Siziba et al., 2011, pp. 180-193). Table 2 below illustrates crops grown by smallholder crop irrigators in the Eastern Cape Province.

Table 2. Crops grown by smallholder farmers in the Eastern Cape Province

\begin{tabular}{lll}
\hline Crops Grown & Percentage & Season \\
\hline Maize & 61.98 & Summer \\
Cabbage & 52.3 & Winter \\
Spinach & 22.15 & Winter \\
Potatoes & 18.5 & Summer \\
\hline
\end{tabular}

\subsection{Estimates of the Heckman Model of Farmers' Decision to Participate in Markets}

Market participation was estimated using the Probit model by analyzing the determinants of irrigated farmers and homestead market participation. In the Probit model, market participation by individual homestead and smallholder irrigators was used as the dependent variable. Based on the results in Table 3 , the Pseudo $\mathrm{R}^{2}$ is $60 \%$, and it is an acceptable level, implying that the model's estimates fit the data. And the $\mathrm{R}^{2}$ is $63 \%$ with a p-value of 0.000 indicating that all the explanatory variables have a significant influence on farmers' decision to participate in the crop markets.

Table 3. Factors influencing farmers' decision to participate in the formal markets

\begin{tabular}{|c|c|c|c|c|c|c|}
\hline \multirow{2}{*}{ Variables } & \multirow{2}{*}{ B } & \multirow{2}{*}{ Std. Error } & \multirow{2}{*}{$\mathbf{T}$} & \multirow{2}{*}{ Sig. } & \multicolumn{2}{|c|}{$\mathbf{9 5 . 0} \%$ Confidence Interval for $B$} \\
\hline & & & & & Lower Bound & Upper Bound \\
\hline (Constant) & 1.075 & .308 & 3.486 & $.001 * * *$ & .467 & 1.683 \\
\hline Age & -.006 & .003 & 2.307 & $.022 * *$ & .001 & .011 \\
\hline Years in school & $.881 * *$ & 0.446 & .107 & $.048 * *$ & -.076 & .085 \\
\hline Distance to market & -.023 & .032 & .714 & $.006 * * *$ & -.041 & .087 \\
\hline Access to Extension services & .044 & .039 & .131 & $.003 * * *$ & .121 & .033 \\
\hline Household size & .546 & .703 & .308 & $.028 * *$ & .243 & .156 \\
\hline Occupation & .090 & .052 & .751 & $.012 * *$ & -.011 & .192 \\
\hline Farm size & -.677 & .353 & .345 & $.045^{* *}$ & -.234 & .163 \\
\hline $\begin{array}{l}\text { Number of observations: } 150 \text {; } \\
\text { Wald chi2 }(14)=185.05 \text {; Prob } \\
\text { R squared: } 63 \% \text {; Pseudo } \mathrm{R}^{2}: 6\end{array}$ & i2 $=0.00$ & 3.6317 & & & & \\
\hline
\end{tabular}

Note. $* * *$ and $* *$ are significant at $1 \%$ and $5 \%$ significant levels, respectively.

Source: Field survey (2016).

The age of smallholder irrigators has a positive substantial effect $(p<0.01)$ on market participation, indicating that an upsurge in farmers' age by 1 year would significantly decrease the likelihood of participation to markets by $0.6 \%$. The results are in line with aforementioned studies predicted a negative coefficient of age on market participation by smallholder farmers (Olwande \& Mathenge, 2012; Munsah, 2013; Enete \& Igbokwe, 2009).

The study results have revealed positive and substancial relationship between years spent in school and market participation at 5\% level. This means that a unit increase in years spent in school by $1 \%$ will result in a unit increase in Mrket participation by farmers by $8.8 \%$. These results agrees with previous studies who found positive relationship between education and market participation as education assist farmers by enhancing production and managerial skills which are important for matket participation and farm operations (Enete \& Igbokwe, 2009; Makhura et al, 2001). Distance to markets was found to be statistical substantial at $1 \%$ and have negative relationship with market participation. This suggests that a unit increase in distance to markets by 1 kilometer would result in a decrease in market participation by farmers by $2.3 \%$. These findings are in line with previous studies that found out that rise in distance would decrease market participation by farmers (Mmbando, 2014; Martey et al., 2012). 
Farm size was found to have an undesirable and substantial association $(\mathrm{p}<0.05)$ with market participation. This denotes that a unit upsurge in farm size by $1 \%$ would significantly reduces the likelihood of participation in markets by $6.77 \%$ by farmers. This highlights the constraints smallholder farmers' face, the majority of farmers who happen to be poor, face problems in retrieving markets probably due to their incapability to yield a marketable surplus. Contact with agricultural extension services was found to be significant in affecting market participation positively and was significant at $5 \%$, which indicates that a unit rise in access to extension services by $1 \%$ would significantly increases the likelihood of participation by $4.4 \%$. The results are in line with studies done by According to Mmbando (2014), and Alene et al. (2008), whose findings found positive relationship between access to extension services and market participation.

Family size was found to be positive and have a substantial effect on market participation. The results suggest that a unit rise in family size by $1 \%$ would significantly increases the likelihood of participation by $15.46 \%$. This means that the household contributed positively to market participation as the majority of the farmers have a low household size, which is associated with participation to markets, unlike high household size, which competes with markets for the harvested yields. Occupation was found to be positive sign and statistical significant at 5\% with market participation, which indicates that those that take farming as their main occupation participate more in the market than any other group and the research findings are consistent with the work (Adeoti et al., 2014).

Since the functional form of the model is extended to formulate second part of the Heckman model, there is a multivariate Ordinary Least Squares (OLS) of volume sold was paired against descriptive variables for smallholder crop irrigators. Thus, an association between the two was recognized and fitted and results are presented in Table 4. This technique was to investigate factors influencing the volume sold in the formal markets using textension of ordinary least square (OLS). The instructive variables were quantified as those correlated to socioeconomic factors of the smallholder farmers.

Table 4. Factors influencing farmers' volume sold to the markets

\begin{tabular}{llll}
\hline Variables & Coefficient B & Standard error & Significance \\
\hline Constant & 2.2133 & 1.1292 & $.002^{* * *}$ \\
Gender & 1.8884 & .6107 & $.000^{* * *}$ \\
Years spent in school & .1613 & .0528 & $.005^{* * *}$ \\
Non-farm income & -.0539 & .0307 & $.002 * * *$ \\
Distance to markets & -.0072 & .0308 & $.002 * * *$ \\
Member of farm organization & -.0203 & .04301 & $.040^{* *}$ \\
Access to extension service & .0153 & .6022 & $.000^{* * *}$ \\
Log-likelihood: -162.4281; Number of observers: 150 & & \\
Wald chi-square: 184.463 ; Probability(chi-square): 0.000 & & \\
Pseudo R $: 0.081 ;$ rho: 1 & & \\
\hline te. $* * *:$ significant at 1\% level; **: significant at 5\% level, respectively.
\end{tabular}

Source: Survey data (2016).

Table 4 presents insights about factors influencing volume sold in the market in the Eastern Cape smallholder sector under maize production. Table 4 presents the results of the OLS and the model do fit to be used. The R Squared value of $81 \%$ and Chi-Square (184.463) which was substantial at $p \leq 0.000$ demonstrating that variables included in the model were exact predictors. Table 4 above shows factors influencing the volume of crop sold by farmers. The instructive variables were measured as those related to socioeconomic factors of the smallholder irrigated crop farmers in the Eastern Cape irrigation schemes.

Gender of the household head was found positive and statistical significant at $1 \%$ with volume of crop sold by 1.8884. These findings are in line with Segei (2014) and Sebatta et al. (2014) that men are expected to sell more due to their intelligence in negotiating, exchanging and enforcing contracts. Years spent in school was found to be positive and substantial at $1 \%$ with volume sold. This suggests that the more years a farmer spend in school, rises the capability of farmers to use their resoueces more effective as well as being able to receive, analyze and interpret information. The more years spent in school by a farmer increases the volume of crop sold to the market by 0.1613 . The findings agrees with Sebatta et al. (2014) that educated farmers are likely to be active in markets and more they supply for market as they take farming as a business. 
Off farm income (non farm) was found to have adverse effect on and substantial volume sold by $1 \%$. This simply means that the more farmers rely and increases off-farm income will decrease volume of crop sold to the market by 0.0539 . The results suggest that farmers with additional income from off-farm will not be enthuasistic to sell and participate in markets as they have alternative income. These results agrees with Enete and Igbokwe (2009) that crop market participants do not invest in off-farm income in farm technology and other farm development activities and tend to trigger off-farm expansion

Distance to markets was statistically significant at $1 \%$ and was negative. This means that an increase to distance to the markets by 1 kilometer, the volume of crop sold to the market decreases by 0.0072 . The results are in line with Mmbando (2014) findings which states that market intensity shows that distance to the market is a gauge of time covered and rate which plays crucial role in volume of crop sold to the markets. Contact with extension services was found positive and statistically significant at $5 \%$ with volume of crop sold. This suggests that the more farmers have contact with extension services the more the farmers sell his or her produce. This suggests that an increase in access to extension services will upturns the volume of crops sold to the markets by 0.0153The contact with extension services, empowers farmers with techniques, skills, knowledge and market information which is important for marketing.

\section{Conclusion}

The aim of the paper was to determine factors influencing decision to participate in markets and volume sold by smallholder irrigators in the Eastern Cape Province. The study was carried out in irrigation schemes in the Eastern Cape Province. Study results discovered that only a limited smallholder irrigated crop farmers do participated in markets of their products, as a result, majority of smallholder irrigators in the Eastern Cape Province do not participate in markets. The reasons for such low participation in markets is coupled by socio-economic, technical and institutional factors which resulted only in four major crops being sold by smallholder irrigators. The main crops sold are Maize, Cabbage, Potatoes, and Spinach. Factors that influence market participation of smallholder irrigators and homestead are age, years spent in school, distance to markets, farm experience and occupation. The volume of crop sold is influenced by gender, years spent in school, non-farm income, and access to extension and distance to markets. Policies aimed at encouraging group marketing, the formation of extra market places for selling and development of near by markets in farming areas around the irrigation schemes in imperative to decrease conveyance expenses and distance to markets to promote market participation.

\section{Acknowledgements}

The authors honestly concede the substantial financial support received from the NRF DAAD-In Country scholarship and Water Research Commission (WRC) for the financial support as well as for providing a conducive environment for accessing the vital resources needed to produce the required documentation of this study. Authors thank the smallholder irrigation farmers and homestead in the Eastern Cape Province for actively participating in this study.

\section{References}

Aliber \& Hall. (2012). Support to Small-scale Farmers: A New Point of Departure.

Adeoti, A. I., Oluwatayo, I. B., \& Soliu, R. O. (2014). Determinants of market participation among maize producers in Oyo state, Nigeria. Brit. J. Econ. Mgt. Tr., 4(7), 1115-1127. https://doi.org/10.9734/BJEMT/ 2014/7826

Alene, A. D., Manyong, V. M., Omanya, G., Mignouna, H. D., Bokanga, M., \& Odhiambo, G. (2008). Smallholder market participation under transactions costs: Maize supply and fertilizer demand in Kenya. Food Policy, 33(4), 318-328. https://doi.org/10.1016/j.foodpol.2007.12.001

Baloyi, J. K. (2010). An analysis of constraints facing smallholder farmers in the Agribusiness value chain: A case study of farmers in the Limpopo Province (MSc Dissertation, University of Pretoria, Pretoria, South Africa).

Basamba, T. A., Kiiza, B., Mayan, C., Nakileza, B., Matsiko, F., Nyende, P., \& Kukunda, E. L. (2012). Linking Markets to Smallholder Agroforestry Farmers as a Strategy for Poverty Alleviation in the Tropics. Journal of Agricultural Science and Technology, 2, 329-338.

Bushoborozi, J. (2013). The profitability of finger millet production in Eastern Uganda (MSc Thesis, Makerere University, Uganda). 
Christian, M. (2015). Assessing the impact of primary agricultural co-operative members on smallholder farm performance (crops) in Mquma Local Municipality in the Eastern Cape Province (MSc Dissertation, University of Fort Hare, Alice, South Africa).

Cousins, B. (2013). Smallholder Irrigation Schemes, Agrarian Reform and Accumulation from Above and from Below' in South Africa. Journal of Agrarian Change, 13(1), 116-139. https://doi.org/10.1111/joac.12000

Cunningham, L. T., Brown, B. W., Anderson, K. B., \& Tostao, E. (2008). Gender differences in marketing styles. Agric. Econ., 38(1), 1-7. https://doi.org/10.1111/j.1574-0862.2007.00225.x

DAFF (Department of Agriculture, Forestry \& Fisheries). (2010). An estimate of the contribution of the agriculture sector to employment in the South African economy. Compiled by Directorate: Economic Services Department of Agriculture, Forestry and Fisheries.

ECDC (Eastern Cape Development Corporation). (2013). About the Eastern Cape: District Maps. Retrieved May 15, 2015, from http://www.ecdc.co.za/the_eastern_cape/district_map

ECDC (Eastern Cape Development Corporation). (2007). Introduction to the Eastern Cape. Retrieved from http://www.ecdc.co.za/easterncape

Fanadzo, M., Chiduza, C., \& Mnkeni, P. N. S. (2009). Comparative response of direct seeded and Transplanted Maize (Zea mays L.) To Nitrogen Fertilization at Zanyokwe Irrigation Scheme, Eastern Cape, South Africa. African Journal of Agricultural Research, 4(8), 689-694.

Enete, A. A., \& Igbokwe, E. M. (2009). Cassava Market Participation Decisions of Producing Households in Africa. Tropicultura, 27(3), 129-136.

Gobena, G. K. (2012). Analysis of smallholder farmer's participation in production and marketing of export potential crops: The case of Sesame in DIga District, East Wollega Zone of Oromia Regional State (MSc Thesis, Addis Ababa University, Addis Ababa, Ethiopia).

Goetz, S. J. (1992). A selectivity model of household food marketing behavior in sub- Saharan Africa. American. Journal of Agricultural Economics, 74, 444-52. https://doi.org/10.2307/1242498

IFAD (International Fund for Agricultural Development). (2010). Rural Poverty in Guinea.

Jagwe, J. (2011). The impact of transaction costs on the participation of smallholder farmers and intermediaries in the banana markets of Burundi, DRC, and Rwanda (PhD Thesis, University of Pretoria, South Africa).

Kibirige, D. (2013). The impact of human dimensions on smallholder farming in the Eastern Cape Province of South Africa (Thesis, University of Fort Hare, Alice, South Africa).

Komarek, A. (2010). The determinants of the banana market commercialization in Western Uganda. African Journal of Agricultural Research, 5(9), 775-784.

Makhura, M. T. (2001). Promoting market participation in small-scale agriculture in the Northern Province. An outline paper presented at a seminar organized by NIEP, LAPC and the University of Pretoria on market access. Agrivillage, Northern Province Department of Agriculture, Pietersburg.

Matsane, S. H., \& Oyekale, A. S. (2014). Factors Affecting Marketing of Vegetables among Small-Scale Farmers in Mahikeng Local Municipality, North West Province, South Africa. Mediterranean Journal of Social Science, 5(20), 390. https://doi.org/10.5901/mjss.2014.v5n20p390

Martey, E., Al-Hassan, R. M., \& Kuwornu, J. K. M. (2012). Commercialization of smallholder agriculture in Ghana: A Tobit regression analysis. African Journal of Agricultural Research, 7(4), 2131-2141.

Mdlalose, N. (2016). Marketing of fresh produce by smallholder farmers: A case study of uThungulu District Municipality, KwaZulu-Natal, South Africa (MSc Dissertation, University of KwaZulu-Natal, Pietermaritzburg, South Africa).

Mmbando, F. E. (2014). Market participation, channel choice, and impacts on household welfare: The case of smallholder farmers in Tanzania (PhD Thesis, University of KwaZulu-Natal, Pietermaritzburg, South Africa).

Musah, A. B. (2013). Market Participation of Smallholder Farmers in the Upper West Region of Ghana (MSc Dissertation, University of Ghana, Legon, Ghana).

Mushunje, A., Belete, A., \& Fraser, G. C. G. (2003). Technical Efficiency of Resettlement Farmers of Zimbabwe. Contributed Paper Presented at the 41st Annual Conference of the Agricultural Economics Association of South Africa (AEASA), October 2-3, 2003, Pretoria, South Africa. 
Nyekanyeka, T. (2011). Analysis of Profitability and Efficiency of Improved and Local Smallholder Dairy Production: A Case of Lilongwemilk Shed Area (MSc Thesis, University of Malawi, Bunda College, Malawi).

Obi, A., \& Pote, P. (2012). Technical constraints to market access for crop and livestock farmers in Nkonkobe Municipality, the Eastern Cape Province. In A. Obi, H. D. Van Schalkwyk, J. A. Groenewald, G. C. G. Fraser, \& A. Van Tilburg (Eds.), Unlocking markets to smallholders: Lessons from South Africa (Mansholt publication series, Vol. 10). Wageningen Academic Publishers, Netherlands. https://doi.org/10.3920/ 978-90-8686-168-2 4

Obi, A., \& Chicago, F. F. (2011). Performance of Smallholder Agriculture under Limited Mechanization and the Fast Track Land Reform Program in Zimbabwe. International Food and Agribusiness Management, 14(4).

Olarinde, L. O. (2011). Analysis of Technical Efficiency Differential among Maize Farmers in Nigeria (Paper 232). African Economic Research Consortium, Nairobi, Kenya.

Olwande, J., \& Mathenge, M. (2012). Market Participation among Poor Rural Households in Kenya. Paper Presented at the International Association of Agricultural Economists Triennial Conference, Brazil.

Samboko, P. C. (2011). An assessment of factors influencing the profitability of bean production in Zambia (Dissertation, University of Zambia, Zambia).

Statistics South Africa (Stats SA). (2012). Food Security and Agriculture (2002-2011): In-Depth analysis of the General Household Survey (General Household Survey Series Volume IV). Pretoria: Statistics South Africa.

Sebatta, C., Mugisha, J., Katungi, E., Kashaaru, A., \& Kyomugisha, H. (2014). Smallholder farmers' decision and level of participation in the potato market in Uganda. Modern Economy, 5, 895-906. https://doi.org/ 10.4236/me.2014.58082

Sergei, G. K. (2014). Determinants of market participation among small-scale pineapple farmers in Kericho County, Kenya (MSc Thesis, Egerton University, Njoro, Kenya).

Siziba, S., Nyikahadzoi, K., Diagne, A., Fatunbi A. O., \& Adekunle, A. A. (2011). Determinants of cereal market participation by sub-Saharan Africa smallholder farmer. Journal of Agriculture and Environmental Studies, 2(1), 180-193.

Young, J. (2013). Investing in the Eastern Cape. Retrieved from http:/www.southafrica.info/business/investing/ opportunities/ecape.htm\#.VTjVK8KKDIV

\section{Copyrights}

Copyright for this article is retained by the author(s), with first publication rights granted to the journal.

This is an open-access article distributed under the terms and conditions of the Creative Commons Attribution license (http://creativecommons.org/licenses/by/4.0/). 